\title{
Learning Direct and Inverse Proportion Using Musi Tour
}

\author{
Nursa Fatri Nofriati, Yusuf Hartono, Somakim \\ Universitas Sriwijaya, Jl. Srijaya Negara, Palembang City, South Sumatra 30128, Indonesia \\ e-mail: nursafatri11@gmail.com
}

\begin{abstract}
This study used design research to produce learning trajectory through Musi Tour context which can help students in understanding the concept of direct and inverse proportion. This study used PMRI approach. The object of this study was the seventh grade students of SMP Nurul Qomar Palembang. Data for retrospective analysis was collected from teaching experiment in the form of students' work results, field notes, and students' interview. The results obtained in this study were learning trajectory which consisted of 3 activities: 1) Students were given contextual problems namely Musi Tour as the starting point in learning direct and inverse proportion, 2) Through students' understanding of the ratio table in the Musi Tour context, students can understand the direct proportion, 3) Students can model and understand the concept of inverse proportion and solve the problems by using Ratio table. The results showed that the use of Musi tour context can help students in understanding the concept of direct and inverse proportion.
\end{abstract}

Key Words: direct and inverse proportion, musi tour, ratio table, design research, PMRI

How to Cite: Nofriati, N.F., Hartono, Y., \& Somakim. (2019). Learning Direct and Inverse Proportion Using Musi Tour. International Journal on Emerging Mathematics Education, 3(2), 139-151. http://dx.doi.org/10.12928/ijeme.v3i2.13578

\section{INTRODUCTION}

The functions of mathematics learning are as a tool, mindset, and science or knowledge. These three functions are used as references in mathematics learning (Suherman, 2003). One of the topics in mathematics learning for junior high school is proportion. Proportion material in middle school is divided into direct and inverse proportion. Lamon (2006) reveals that the direct proportion is proportion that the change of the value of one quantity followed by a change in another quantity, with the same change. Meanwhile inverse proportion is proportion that the change of the value that occurs in one quantity followed by a change in another quantity, and the value of the change is opposite.

Based on the interview with seventh grade students of SMP Nurul Qomar Palembang and some previous studies that there were still many students who still did not understand the material of direct and inverse proportion. According to Sumarto (2013), the thing that causes students' mistakes in understanding the proportion material is one of them caused by teaching the concept of proportion, the teacher gives the formula by using algebraic and cross multiplication notation. Moreover, according to Norton (2005), confronting students on multiplication and division problems, it has not been effective in helping students to develop a deeper understanding of reasoning about proportion. Therefore, by using this method, students can do proportion questions, yet students will not get how the concept of proportion itself.

Poor understanding of proportion material, contributes to the poor of the use of arithmetic knowledge, such as in managing multiplication problems, making boundaries, and changing the forms of concepts faced in secondary education, such as 
learning about functions (Ruiz \& Lupianez, 2009). According to Lamon (2006), a student can have a strong sensitivity to the size and characteristics of quantities, such as speed, and can use the appropriate vocabulary (eg, miles per hour) correctly without realizing the relationship between the numbers that make up the proportion. Understanding of these relationships is the key for someone to be able to understand the concepts of mathematics which are more complex, as well as problems in daily life related to proportion (Raharjanti, Nusantara, \& Mulyati, 2016). Therefore, it needs the learning which can help comprehending students' concepts of direct and inverse proportion material.

One of the ways to teach proportion material can be done by exploration activity (Cramer \& Post, 1993; Van de Walle, 2008). Exploration activity of proportion material can include situations involving measurement, price, geometry, or other visual contexts or various rates (Van de Walle, 2008). By conducting exploration activities using a broad context, so that mathematical ideas emerge (Rahmawati, 2015; Andinasari, 2016). According to Streefland (1985), proportion can be taught using the Ratio table. Ratio table is used as a tool to introduce understanding of ratio and proportion in elementary and secondary mathematics education in the Netherlands. Ratio Table is reported as a commonly used tool in the early stages of proportion reasoning (Carpenter et al., 1998; Kaput \& West, 1994). This is in line with Sumarto (2013) who states that this table is a good tool for calculating and helping students to understand the main material. Proportion table along with context can help students to develop proportion reasoning and as proportion problem solving strategy.

One of the approaches in mathematics learning that uses context is a realistic mathematical approach. The use of context is the first characteristic of PMRI (de Lange, 1998; Zulkardi \& Putri, 2006). Context is used as the starting point in learning (Zulkardi, 2002). The situations that can be used as contexts include personal, educational, public and scientific (de Lange, 1987; OECD, 2009). Several previous studies have also obtained maximum results in proportion learning using the context with PMRI approach, those are in Utari's study (2015) showed that through a series of activities that have been designed can help students to gain understanding from using their intuition informally towards formal in solving proportion problems using Palembang cultural context. Then, this is also shown by the study conducted by Andinasari (2016) which showed that the results of using take-off plane video can support students' conceptual understanding of the inverse proportion material in VII grade. From the results of previous studies using PMRI approach, it shows that PMRI approach is very good to be applied in proportion material and other materials.

According to Hauvel-Panhuizen (1996), the situation of students' lives is not only what is real in the views of students but also everything that can be imagined by students, affordable by their imagination. In mathematics learning with this approach, students have the opportunity to rediscover mathematical concepts through activities that they experience themselves. In learning, it needs to start from something real and close to the students' lives (Pitadjeng, 2015). The context used in this study is Musi Tour context. This musi tour context is used as starting point on mathematics learning because this context is very close to the students' daily lives in Palembang and can encourage students to find mathematical concepts. In this context, there are situational problems related to proportion. Furthermore, through this context, it is expected to be able to support students' ability to understand the concepts of direct and inverse proportion.

IJEME, Vol. 3, No. 2, September 2019, 139-151. 
According to the explanation above, the research question of this article is "how does learning trajectory of direct and inverse proportion use Musi Tour context in helping students to understand the concept of direct and inverse proportion".

\section{RESEARCH METHOD}

The research method is design research which produces a learning trajectory in the learning of the combination concept by using handshake context. Design research aims to develop a local instructional theory which is based on the existing theory (theory-driven) and empirical experiment (empirically based) through cooperation between the researcher and the teacher to improve the relevancy of this research with educational policy and practice (Gravemeijer \& Van Eerde, 2009). According to (Gravemeijer, 1994), design research has three phases, which are: preparing for the experiment, the design experiment, and the retrospective analysis. In the phase of preparing for the experiment, researcher reviewed all literature which would be used in the research to produce learning trajectory or Hypothetical Learning Trajectory. Hypothetical Learning Trajectory is designed with the containing of anticipation for possible occurrences. Before designing, the researcher determined to learn purpose or aimed purpose and initial point of learning. Table 1 shows the instructional activities and students' conjectures.

Table 1. The instructional activities of Design Research

\begin{tabular}{|c|c|c|c|c|}
\hline $\begin{array}{l}\text { Learning } \\
\text { Goal }\end{array}$ & Activity & Tools & $\begin{array}{c}\text { Conjecture of Students' } \\
\text { Strategies }\end{array}$ & $\begin{array}{c}\text { Conjecture of } \\
\text { Students' Difficulties }\end{array}$ \\
\hline $\begin{array}{l}\text { students } \\
\text { can know } \\
\text { and } \\
\text { understand } \\
\text { the two } \\
\text { quantities } \\
\text { proportion }\end{array}$ & $\begin{array}{l}\text { Understanding } \\
\text { and exploring } \\
\text { their } \\
\text { knowledge } \\
\text { using Musi } \\
\text { Tour context }\end{array}$ & $\begin{array}{l}\text { Students' } \\
\text { worksheets } \\
\text { with Musi } \\
\text { Tour } \\
\text { context }\end{array}$ & $\begin{array}{l}\text { - Students observe and share } \\
\text { their experiences while doing } \\
\text { Musi Tour tours } \\
\text { - Students inform many } \\
\text { passengers of each boat and } \\
\text { state in the form of ratio. } \\
\text { - Students are asked to observe } \\
\text { the Musi Tour tour package } \\
\text { table and make a sentence } \\
\text { comparing the rates for each } \\
\text { boat that has the same } \\
\text { destination } \\
\text { - Students are asked to } \\
\text { conclude that the incident is } \\
\text { comparing two equal } \\
\text { quantities }\end{array}$ & $\begin{array}{l}\text { Students may } \\
\text { experience difficulties in } \\
\text { stating many passengers } \\
\text { in each boat in the form } \\
\text { of ratio. } \\
\text { In this case, the } \\
\text { researchers anticipate } \\
\text { the teacher so that } \\
\text { teacher can attract } \\
\text { students to remember } \\
\text { the fraction form. }\end{array}$ \\
\hline $\begin{array}{l}\text { Students } \\
\text { can know } \\
\text { and } \\
\text { understand } \\
\text { direct and } \\
\text { inverse } \\
\text { proportion }\end{array}$ & $\begin{array}{l}\text { Students use } \\
\text { model which } \\
\text { they made by } \\
\text { themselves } \\
\text { with the aid of } \\
\text { Musi Tour } \\
\text { context in the } \\
\text { form of a boat } \\
\text { that will be } \\
\text { filled with } \\
\text { tourists and } \\
\text { students use } \\
\text { Ratio Table to } \\
\text { understand } \\
\text { direct and } \\
\text { inverse } \\
\text { proportion }\end{array}$ & $\begin{array}{l}\text { Students' } \\
\text { worksheets } \\
\text { with Musi } \\
\text { Tour } \\
\text { context, } \\
\text { Boats are } \\
\text { made of } \\
\text { stick ice, }\end{array}$ & $\begin{array}{l}\text { - Students determine how many } \\
\text { boats are needed to transport } \\
\text { a number of passengers that } \\
\text { have been determined } \\
\text { - Students determine a number } \\
\text { of passengers who can be } \\
\text { transported by a number of } \\
\text { existing boats } \\
\text { - Students can copy data } \\
\text { obtained from previous } \\
\text { activities into the table } \\
\text { - Students observe the table and } \\
\text { answer that more boats are } \\
\text { needed } \\
\text { - Students observe the table and } \\
\text { answer that fewer boats are } \\
\text { also needed }\end{array}$ & $\begin{array}{l}\text { Students may be little } \\
\text { bit confused in drawing } \\
\text { conclusions from the } \\
\text { relationships that occur } \\
\text { between many boats } \\
\text { and passengers, and } \\
\text { students are confused } \\
\text { whether they use line } \\
\text { graphs or bar graphs }\end{array}$ \\
\hline
\end{tabular}




\begin{tabular}{|c|c|c|c|c|}
\hline $\begin{array}{l}\text { Learning } \\
\text { Goal }\end{array}$ & Activity & Tools & $\begin{array}{c}\begin{array}{c}\text { Conjecture of Students' } \\
\text { Strategies }\end{array} \\
\end{array}$ & $\begin{array}{c}\text { Conjecture of } \\
\text { Students' Difficulties } \\
\end{array}$ \\
\hline & & & $\begin{array}{l}\text { - Students can write on the ratio } \\
\text { table, two rows of data } \\
\text { obtained from the previous } \\
\text { table } \\
\text { - Students can write proportion } \\
\text { from both rows and can form } \\
\text { equations from proportion of } \\
\text { the left and right column } \\
\text { - Students can graph from the } \\
\text { existing data in the previous } \\
\text { table and connect each } \\
\text { existing point } \\
\text { - Students observe and } \\
\text { conclude that a straight line is } \\
\text { formed from the graph they } \\
\text { have made }\end{array}$ & \\
\hline $\begin{array}{l}\text { Resolve the } \\
\text { direct and } \\
\text { inverse } \\
\text { proportion } \\
\text { problems }\end{array}$ & $\begin{array}{l}\text { Students can } \\
\text { find results } \\
\text { from direct } \\
\text { and inverse } \\
\text { proportion in } \\
\text { more complex } \\
\text { forms }\end{array}$ & $\begin{array}{l}\text { Tour } \\
\text { Students' } \\
\text { worksheets } \\
\text { with Musi } \\
\text { Tour } \\
\text { context }\end{array}$ & $\begin{array}{l}\text { - Students are given more } \\
\text { complex problems that are } \\
\text { still related to the context of } \\
\text { the Musi Tour }\end{array}$ & $\begin{array}{l}\text { Students may still have } \\
\text { difficulty in describing } \\
\text { their own problems and } \\
\text { explaining the strategies } \\
\text { they use }\end{array}$ \\
\hline
\end{tabular}

The phase of design experiment is divided into two cycles, which are the pilot experiment and the teaching experiment. Pilot experiment or initial experiment of this research is known as a bridge between a phase of initial design and phase of teaching experiment. The purpose of this research is to test initial Hypothetical Learning Trajectory. The main objective of this phase is to collect data for supporting correspondence with the initial Hypothetical Learning Trajectory. In this phase, Hypothetical Learning Trajectory which has been designed was tested to students in a non-research-subject class. Next is teaching experiment, which in its cycle has data collection activity to answer the research question.

The phase of teaching experiment is the implementation of Hypothetical Learning Trajectory which has been improved and implemented in a real class. The purpose is to explore student strategy and thinking in a real learning, as data which will be used to answer the research question (Gravemeijer, 1994; Bustang et al., 2013).

The last phase is retrospective analysis. All of the obtained data analyzed retrospectively were used to plan a learning activity or to develop a design on the next learning activity, with a purpose of developing Local Instructional Theory. In this phase Hypothetical Learning Trajectory is compared to student real learning process to answer the research formulated problem. The research phases can be seen in Figure 1. 


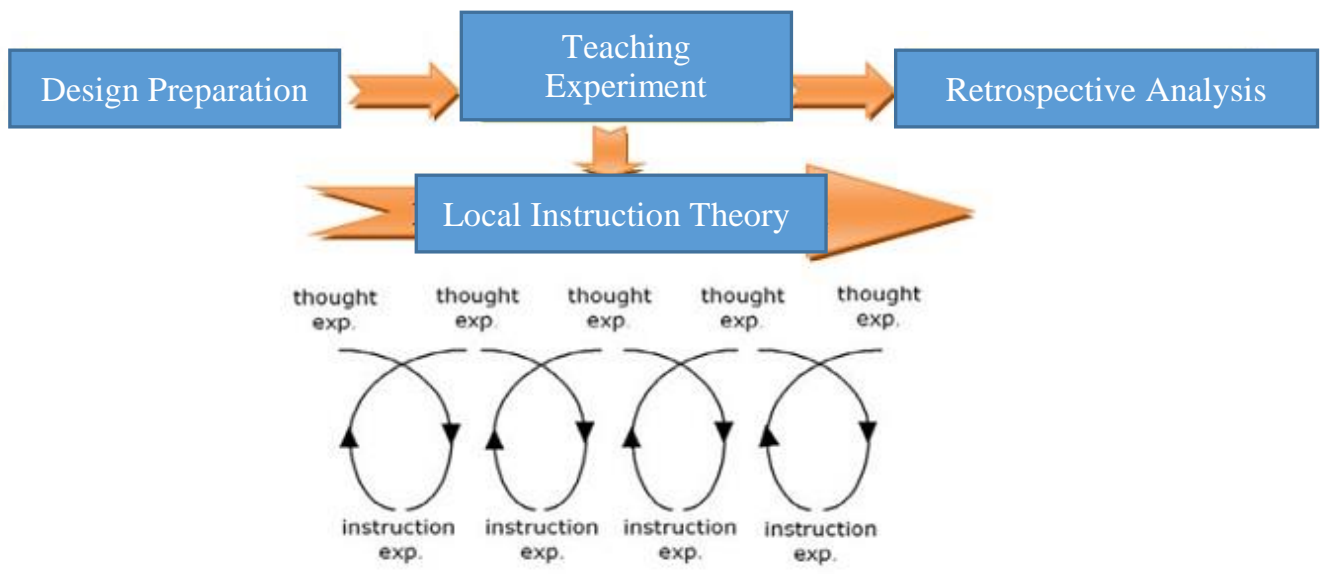

Figure 1. Design Research Phases

\section{RESULTS AND DISCUSSION}

The teaching experiment was conducted in class IV A in SMP Nurul Qomar Palembang with 32 students. Mr. Okmi Wiranda, M.Pd as the classroom teacher will be the model teacher at this stage. In the implementation of learning, the teacher divided students into 2 groups consisted of 7 students (groups 1-2) and 3 groups consisted of 6 students (groups 3-5). Group division was based on homogeneous abilities between groups with heterogeneous abilities in each group, where each group consisted of high, medium, and low ability students.

At the stage of implementing of teaching experiment, researchers acted as observers by looking at students' strategies in solving the problems given, HLT used in the teaching experiment was a revised result of HLT on the pilot experiment. Figure 1 shows the HLT.

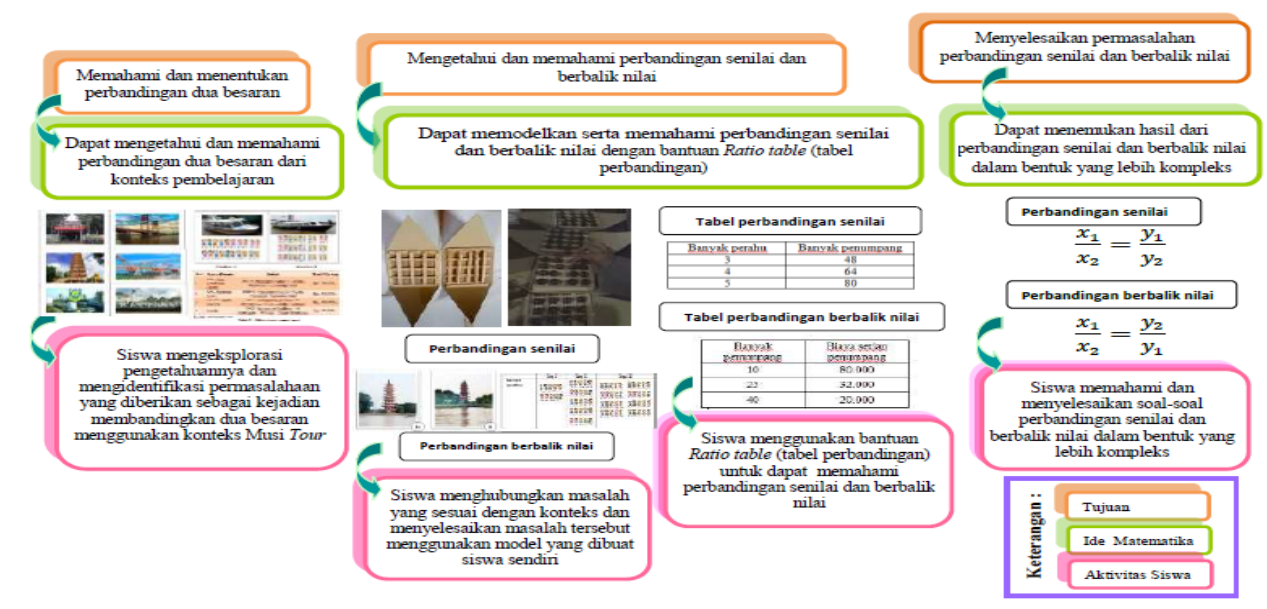

Figure 2. Hypothetical Learning Trajectory (HLT)

\section{Activity 1}

The first problem on LAS 1 was the introduction of Musi Tour context by asking students to share their experiences in traveling to visit tourist attractions along Musi River. Then, students were given problems related to the context of Musi tour with the aim to understand and determine the proportion of two qusntities.

When students were asked to solve problems, most groups have been able to answer questions correctly. This is in accordance with HLT designed. The following transcript shows more details. 
(Problem 1)

Student : Is the above problem an event that compares two equal quantities? Explain!

Teacher : The answer is yes or no?

Student : Yes (exclaiming)

Teacher: What is the reason?

Students : They both compare many members

(Problem 2)

Teacher : What do you want to compare first?

Student : Quantities

Teacher : Quantities? What quantities is there?

Student : Rates

Teacher: Is there same destination?

Student : Yes, there is

Teacher : So can it be compared?

Student : Yes, it can

(Problem 3)

Teacher : Okay, so is the incident comparing the same or different quantities?

Student : Same quantities

Teacher : Same, what is compared?

Student : Km per hour

Teacher : Do km and hour have the same quantities?

Student : No, they don't

Teacher :Yes, will it be the same or different?

Student : Different

Based on the conversation above, it can be seen that students can understand that the problem given is an incident comparing two quantities. The students' answers are shown in Figure 3.

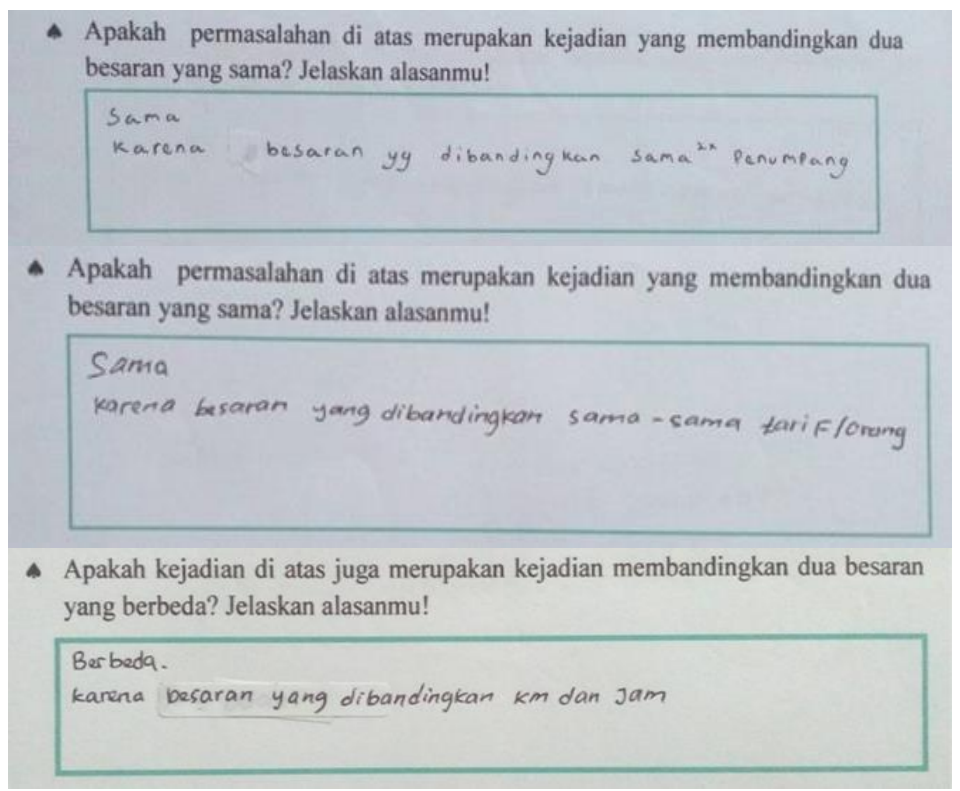

Figure 3. Students' answers distinguish the proportion of two equal quantities and with proportion of two different quantities 
Based on Figure 3 and the conversation between the teacher and students showed that students were able to understand and know that incident is included in the the proportion of two equal quantities or proportion of two different quantities.

\section{Activity 2}

Activity 2 aimed to find out and understand the direct proportion and solve the direct proportion problem with Ratio table's aid.

When students worked on problems on LAS 2 activity 1, most students were enthusiastic when conducting experiments making proportion boat in determining the number of water buses used for some passengers to be transported and many passengers who will be transported for a number of available water buses. After a few minutes, the teacher looked at the students' work and asked the students about the answer in the following transcript.

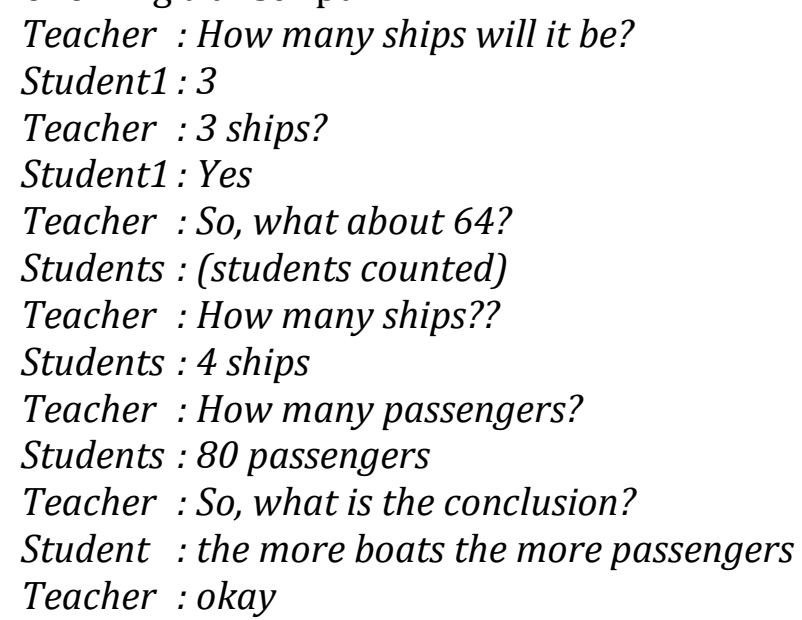

Based on the transcript of the conversation, it can be seen that the given context and assisted with questions at each stage, students were able to understand the direct proportion, even though they have not used the proper language. However, when the students were asked, they were able to explain their intentions and conclusions. In this activity, students made model of that is "Proportion Boat" to help understanding the concept of direct proportion. As proportion boat that have been made by students in Figure 4.

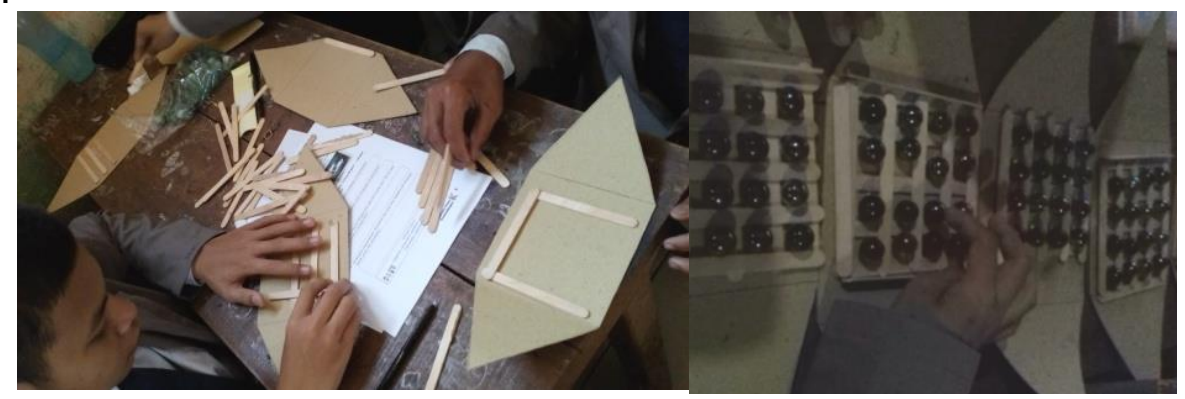

Figure 4. Boat model made by students

Then, from these experiments, students can draw the conclusion that the more boats the more passengers can be transported, and the fewer boats fewer passengers can be transported. The student's answer is shown in Figure 5. 


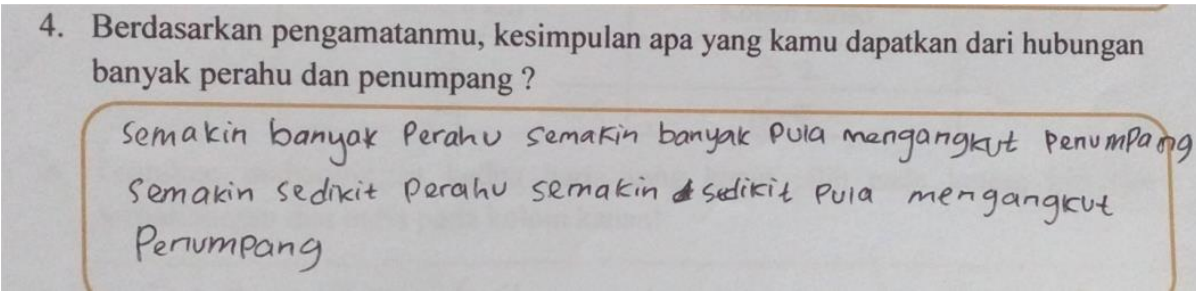

Figure 5. The conlusion made by students

Based on Figure 5, students were able to draw conclusions from the relationship between the number of passengers and the number of boats from the experiments they had done. Then, they have understood that the activity they were doing is direct proportion. Next, the students copied the data they have obtained after experimenting into the tables they have made by themselves and by the Ratio table's aid students solved the problems given as shown in Figure 6.

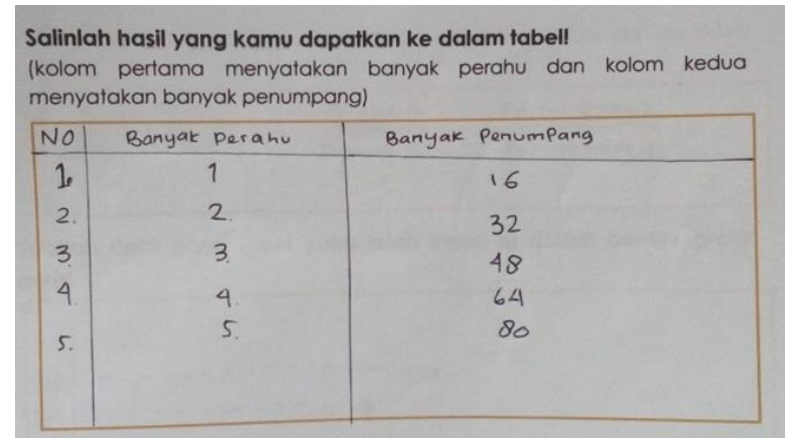

Figure 6. Table made by students

This is the conclusion students got from the direct proportion they have done in Figure 7.

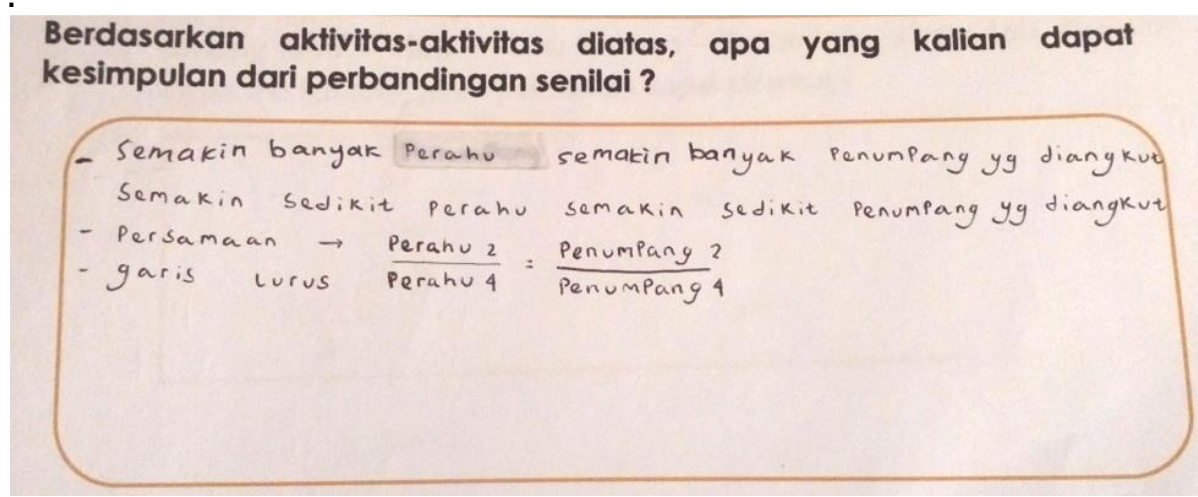

Figure 7. The conclusion made by students

In Figure 7 above, it can be seen that students have been able to draw conclusions well based on the activities and problems they have worked on together. This is in accordance with HLT that has been designed. The next problem, students were asked to solve the problem of direct proportion, namely reading the map of the Musi river flow to determine the distance traveled by a ship and determine the time needed to travel the distance from the ship's trip route. Below is the Conversation Transcript. 
(learning activities 2, question number 1)

Students $\quad$ : BKB to Ki Marogan 3 Mosque, Ki Marogan Mosque to Lawang Kidul 3, Lawang Kidul to Pusri 6, Pusri to Kemaro Island 3, Kemaro Island to Pertamina 4, Pertamina to Lais River 1.5. So, it means $3+3+6+3+4+1.5=27 \mathrm{~km}$

Teacher : how much?

Student : 27

(learning activities 2, question number 2)

Student :If $27 \mathrm{~km}$ is the distance. That means the time is $x . S 0,9$ per 27 is equal to 1 per $x, x=3$

Teacher : What proportion is that?

Student : Direct proportion

From the conversation transcript 3 above, students were able to solve the direct proportion problem with ratio table's aid. The students' answers are shown in Figure 8.

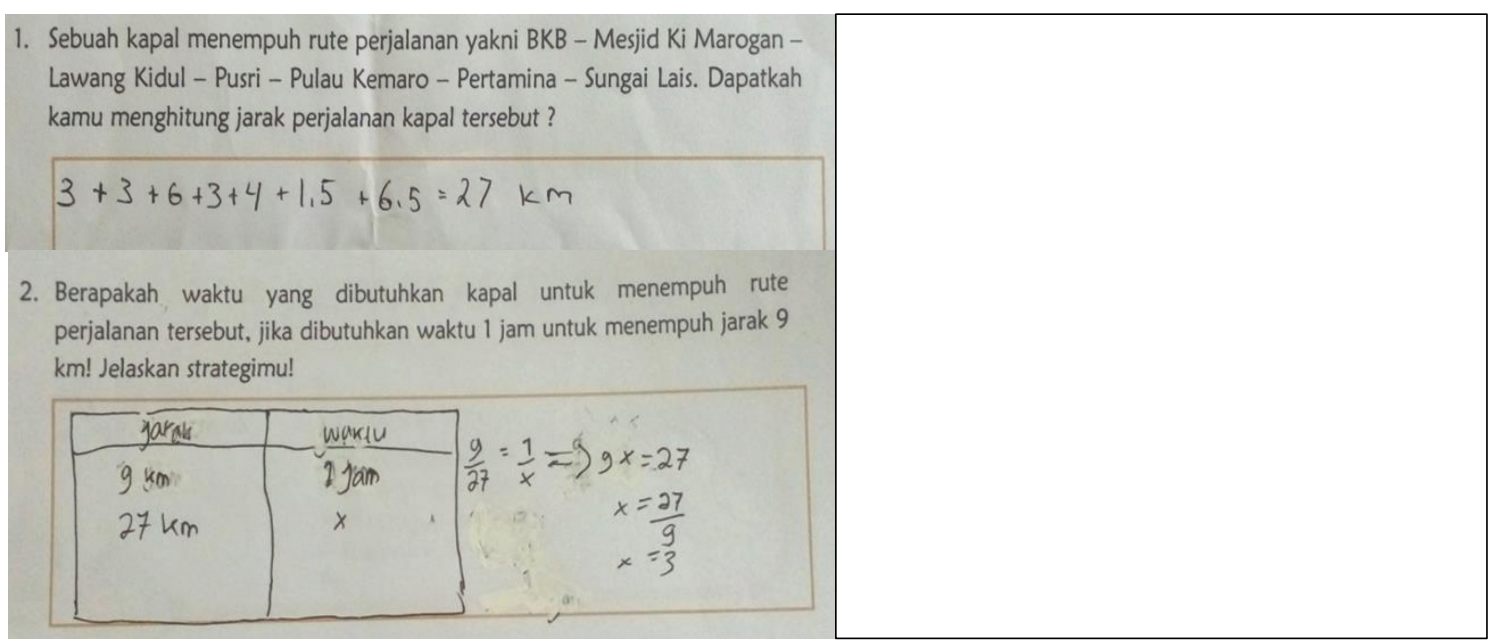

Figure 8. Students' Answers on LAS 2

\section{Activity 3}

In activity 3, this still used Musi tour context. Students were given a problem that required them to sketch Pagoda size change images with different distances and concluded based on the observation from the sketches they have made and knew that the relationship between shooting distance and Pagoda size is inverse proportion. The conversation transcript can be seen in the conversation transcript below.

(activity 1 problem 1)

Student : Because of taking photos is closer

Teacher : If it's not closer? How is the picture?

Student : Big

Teacher : If it is further?

Student : Smaller

(activity 2 problems 2 )

Students : 1 person 80,000, 10 people 800,000. So, for trip 1, there are 10 people

Teacher : Okay, then for trip 2, how is that?

Students : 1 person 32,000 times 10 . So, it is 320,000 
Teacher : Why is it multiplied by 10

Student : Because it is easier to count if it is multiplied by 10

Based on the conversation transcrip, it can be seen that the context was given and assisted with questions in each stage, students were able to understand the inverse proportion, even though they have not used the proper language. However, when they were asked, they were able to explain their intentions and conclusions. In this activity, the students made model of, that is sketching a Pagoda image to help understanding the concept of inverse proportion. The pagoda sketches that have been made by students are shown in Figure 9.

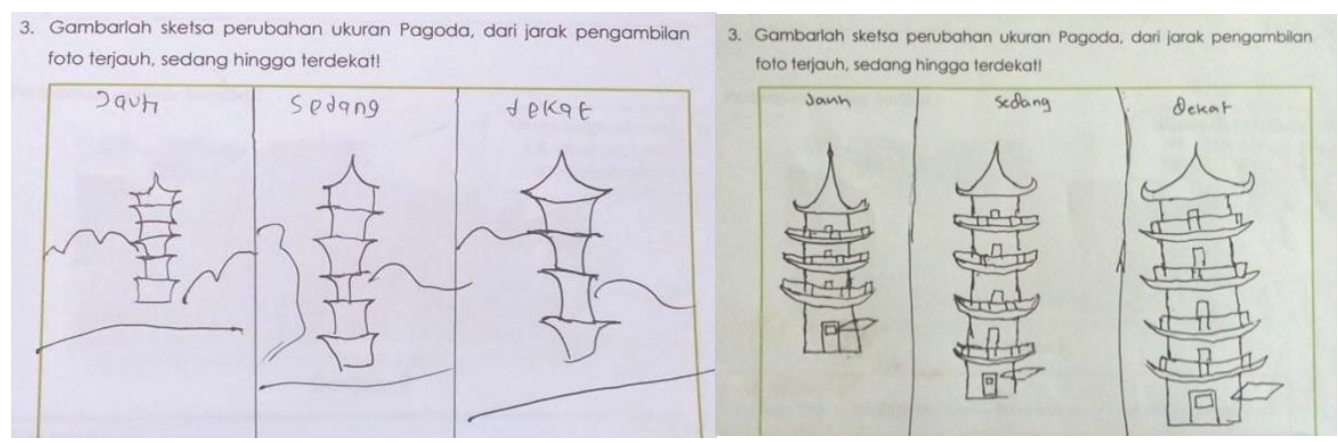

Figure 9. Sketch of Pagoda made by students

Then, from their observations, students have been able to draw conclusions from the relationship of distance and size of pagoda. The student's answer is shown in this Figure 10.

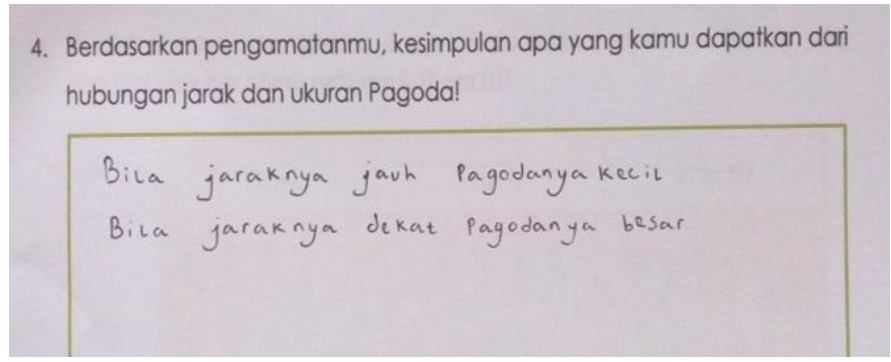

Figure 10. The student's answer

Based on Figure 10, students were able to draw conclusions from the relationship of distance and size of pagoda. Then, they understood that the activity they were doing is inverse proportion. After that, students were given the problem that is determining the number of passengers were transported by a ship that has a certain rental price, where each passenger paid at different costs for each trip made by the ship. In this case, students drew illustrations of the number of passengers on each trip and used Ratio table to solve the problem given. The students' answers are shown in Figure 11. 


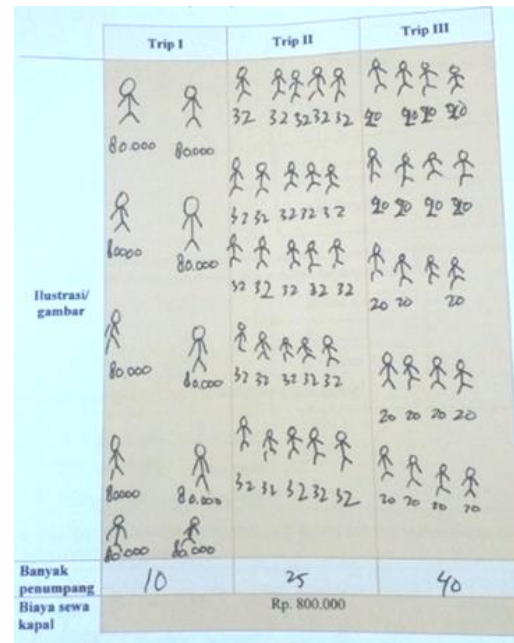

Kemudian salinlah hasil yang kamu dapatkan ke

(kolom pertama menyatakan banyak penumpan

menyatakan biaya yang diterima Pak Mardi dari setiar

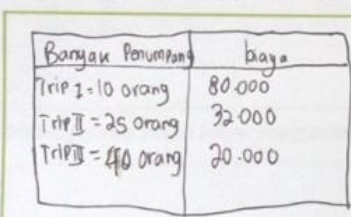

Kemudian salinlah hasil yang kamu dapatkan ke dalan (kolom pertama menyatakan banyak penumpang do menyatakan biaya yang diterima Pak Mardi dari setiap pen

Figure 11. The students' answers on LAS 3 activity 1

Based on Figure 11, it can be seen that students have been able to make illustrations in the illustration table of the number of passengers in each trip and wrote it in the ratio table. The following are the conclusions that students got from inverse proportion they have worked in Figure 12.

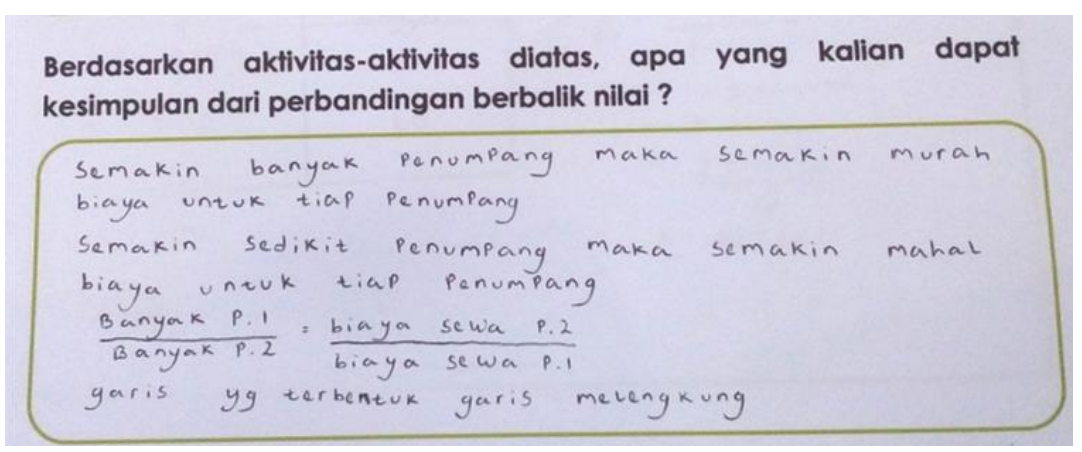

Figure 12. The student's answer on activity 1

In Figure 12, it can be seen that students have been able to draw conclusions about inverse proportion well based on the activities and problems they have done together. This is in accordance with HLT that has been designed.

In learning activities 2 on LAS 3, students were asked to solve the problem of inverse proportion, but in this activity, students were allowed to solve the problem given using ratio table or using the form of equations. Following is the conversation transcript about the problem of inverse proportion.
Student
: So, it becomes 1 per 60 equal to x per Rp. 9,000,000
Teacher
: Why is it inversed?
Student : Because this is inverse proportion
Teacher : Okay, then?
Student : $x$ equals to150,000
Teacher : What is 150,000?
Student : Costs for 60 people?
Teacher : For 60 people?
Student :Oh no, for each passenger 
From the conversation transcript 5 above, students were able to solve the problem of inverse proportion with ratio table's aid. The student's answer is shown in Figure 13.

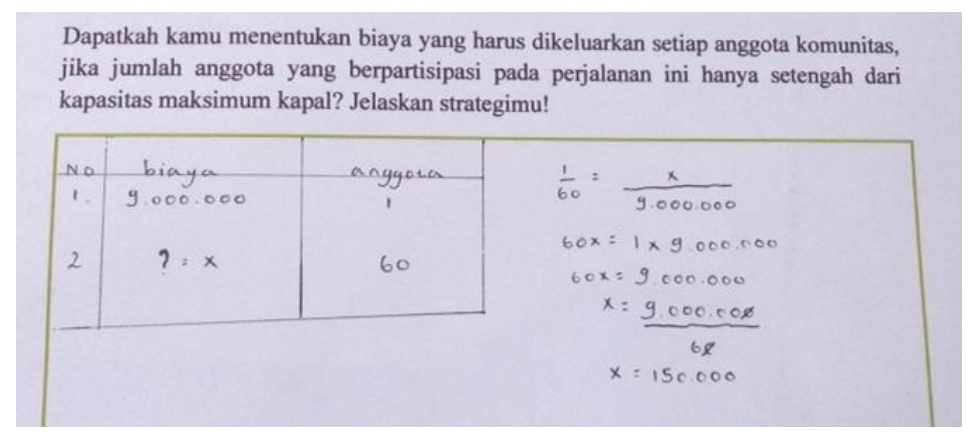

Figure 13. The student's answer on LAS 3

Next, after class discussion, the teacher and students concluded the lesson that inverse proportion is not the same as direct proportion. Both proportion are opposite so the result of equation of proportion is also different from direct proportion. The method that can be used is with ratio table's aid and proportion equation. At last, the teacher closed the lesson.

\section{CONCLUSION}

This study produced a learning trajectory using Musi Tour context, it was seen that the context of Musi tour was very important in helping students to understand direct and inverse proportion. The context given also influenced students in recognizing and distinguishing situations related to direct and inverse proportion. The learning trajectory produced is in the form of trajectories that helped students from the learning process that went through starting from students explored their knowledge to understand and determine the proportion of two quantities from the learning context, students could model and understood direct proportion and solved problems with Ratio table's aid, and students could model and understood the concept of inverse proportion and solved problems with Ratio table's aid.

\section{REFERENCES}

Andinasari. (2016). Penggunaan Video Pesawat Take off pada Materi Perbandingan Berbalik Nilai melalui Pendekatan Matematika Realistik Indonesia. Prosiding Seminar Pendidikan Nasional, Palembang, 1(1), 92-104.

Bustang, et al., (2013). Developing a local instruction theory for learning the concept of angle through visual field activities and spatial representations. International Education Studies, 6, 58-69.

Carpenter, T. P., Franke, M. L., Jacobs, V. R., Fennema, E., \& Empson, S. B. (1998). A longitudinal study of invention and understanding in children's multidigit addition andsubtraction. Journal for Research in Mathematics Education, 29(1), 320.

Cramer, K., Post, T., \& Currier, S. (1993). Learning and Teaching Ratio and Proportion: Research Implications. InD Owens(Ed). Research Ideas For The Classroom (pp.159178). New York: Macmillan Publishing Company.

Gravemeijer, K. (1994). Developing realistic mathematics education.Utrecht: Teehnipress, Culemborg.

Gravemeijer, K,., \& Van Eerde, D. (2009). Research as a Means for Building a Knowledge Base for Teaching in Mathematics Educations. The Elementary School Journal, 109(5), 510-524. 
Kaput, J., \& West, M. M. (1994). Missing-value proprotional reasoning problems:Factorsaffecting informal reasoning patterns. In G. Harel \& J. Confrey (Eds.), The development ofmultiplicative reasoning in the learning of mathematics (pp. 237-292). New York: State University of New York press.

Lamon, S. J. (2006). Teaching Fractions and Ratios for Understanding: Essential Content Knowledge and Instructional Strategies for Teachers 2nd Ed. Lawrence Erlbaum Associates.

Lange, Jan de.. (1998). Assessment: No Change Without Problems. Netherlands: Freudenthal Institute.

Lange, Jan de. (1987). Mathematics, insight and meaning. Utrecht: OW \& OC, Rijksuniversiteit Utrecht.

Norton, S. J. (2005). The Construction of Proportional Reasoning. Proceedi-ngs of the $29^{\text {th }}$ Conference of the International Group for the Psy-chology of Mathematics Education, Melbourne, 4, 17-24.

OECD. (2009). Learning mathematics for life. A view perspective from PISA. Paris: OECD.

Pitadjeng. (2015). Pembelajaran Matematika yang Menyenangkan. Yogyakarta: Graha Ilmu.

Raharjanti, M., Nusantara, T., \& Mulyati., S., (2016). Kesalahan siswa dalam menyelesaikan permasalahan per-bandingan senilai dan berbalik ni-lai. Prosiding KNPMP1 Surakarta, 312-319.

Rahmawati. (2015). Desain Pembelajaran Perbandingan dengan Mengguna-kan Kertas Berpetak di Kelas VII. Thesis. Palembang: Magister Pendidikan matematika FKIP Universitas Sriwijaya.

Ruiz, E. F. \& Lupianez, J. L.. 2009. Detecting Psychological Obstacles to Teaching and Learning The Topics of Ratio and Proportion in Sixth Grade Primary Pupils. Electronic Journal of Research in Educational Psychology (EJREP), 7(17), 397-424.

Streefland, L. (1985). Search for the roots of ratio: some thoughts on the long term learning process (towards.. a theory). Educational Studies in Mathematics, 16, 7594.

Suherman, E., Turmudi, \& Suhendra. (2003). Common Textbook: Strategi Pembelajaran Matematika Kontemporer. Bandung: JICA-Universitas Pendidikan Matematika (UPI).

Sumarto, N. (2013). Design Research on Mathematics Education: Ratio Table In Developing The Students' Proporsional Reasoning. Palembang: Sekolah Pasca Sarjana Universitas Sriwijaya.

Utari, R. S., Putri, R.I.I, Hartono, Y. (2015). Konteks kebudayaan Palembang untuk mendukung kemampuan bernalar siswa SMP pada materi perbandingan. Jurnal Didaktik Matematika. 2(2). 27-37.

Van den Heuvel - Panhuizen, M. (1996). Assessment and realistic mathematics education. Utrecht: CD $\beta$ Press/ Freudenthal Institude.

Van De Walle, J.A (2007). Matematika Sekolah Dasar dan Menengah: Pengembangan Pengajaran Jilid Pertama. Suyono. Jakarta: Erlangga. (2008).

Zulkardi. (2002). Developing a learning environment on realistic mathematics education for Indonesia students teacher. Thesis University of Twente. Netherlands: Print Patners Ipskamp-Enschede.

Zulkardi \& Putri, R.I.I. (2006). Mendesain sendiri soal kontekstual matematika. Prosiding KNM 13, Semarang, 1-7. 